\title{
APLIKASI WISATA KULINER KOTA KUDUS BERBASIS ANDROID
}

\author{
Tri Listyorini ${ }^{1)}$ Rizkysari Meimaharani ${ }^{2)}$ \\ 1) Teknik Informatika Universitas Muria Kudus \\ Gondang Manis POBOX 53 Bae Kudus \\ email : trilistyorini@umk.ac.id \\ 2) Teknik Informatika Universitas Muria Kudus \\ Gondang Manis POBOX 53 Bae Kudus \\ email : rizkyumk12@gmail.com
}

\begin{abstract}
Kota Kudus merupakan daerah industri dan memiliki wisata yang menarik. Letaknya yang strategis dan terkenal dengan kota kretek dikarenakan banyak industri di dalamnya. Selain itu Kudus juga merupakan kota kuliner, banyak makanan khas Kudus yang sudah menjadi makanan nasional dan dikenal oleh masyarakat Indonesia. Selain makanan tradisional, kota Kudus juga terkenal dengan produksi jenang Kudus. Bagi masyarakat luar Kudus yang akan berwisata kuliner di Kudus mengalami kesulitan untuk menemukan letak dari penjual. Untuk itu diperlukan sebuah aplikasi yang dapat membantu masyarakat umum dalam memperoleh informasi kuliner yang ada di kota Kudus. Oleh karena itu untuk mewujudkan aplikasi ini, peneliti menggunakan pendekatan prototype dalam penyusunan penelitian ini. Semakin berkembangnya sistem operasi android di Indonesia, maka peneliti memadukan aplikasi ini berbasis android. Hasil dari penelitian ini menghasilkan sebuah aplikasi kuliner kota Kudus berbasis android.
\end{abstract}

\section{Key words}

kuliner kudus, android, prototype

\section{Pendahuluan}

Kudus merupakan salah satu kabupaten yang terletak di Jawa Tengah yang mempunyai luas wilayah paling kecil di Pulau Jawa bahkan di Indonesia. Kabupaten Kudus berbatasan langsung dengan Kabupaten Pati di sebelah timur, Kabupaten Demak dan Kabupaten Purwodadi di sebelah selatan dan berbatasan langsung dengan Kabupaten Jepara di sebelah barat dan utara. Menurut para sejarawan, Kota Kudus dahulu berasal dari sebuah desa kecil di tepi Sungai Gelis yang bernama Desa Tajug. Para pedagang yang berasal dari Timur Tengah, Tiongkok, maupun pedagang Nusantara juga berdagang kain, barang pecah belah, dan hasil pertanian di Desa Tajug. Sejak saat itulah Tajug menjadi salah satu lokasi perdagangan yang cukup ramai di Pulau Jawa [1].

Dari asal usul kota Kudus yang memiliki semboyan GusJiGang (Bagus Ngaji dan Dagang), masyarakat Kudus mengembangkan usaha di bidang Dagang. Seiring perkembangan waktu, masyarakat Kudus mengembangkan usaha di bidang kuliner makanan khas Kudus. Seperti yang di ulas pada pojoksatu.id menyatakan kuliner Kudus juga tergolong khas, karena tidak semua tempat atau kota bisa dijumpai jenis-jenis masakan itu. Seperti Lenthog Tanjung, atau lentog. Soto Kudus salah satu kuliner khas Kudus yang sudah terkenal senusantara. Ada dua jenis soto kudus, yaitu soto ayam dan soto kerbau [2].

Wisatawan Kudus pada tahun 2015 mengalami penurunan, seperti yang dikutip pada isknews.com menyatakan grafik angka kunjungan wisata di Kudus mengalami penurunan. Data dari Dinas Kebudayaan dan Pariwisata Kabupaten Kudus, yang dihimpun isknews.com, Rabu (29/7), menyebutkan, dilihat dari angkanya, jumlah wisatawan yang berkunjung ke Kudus, dalam tiga tahun terakhir, menunjukkan penurunan. Pada 2012, jumlah wisatawan itu mencapai sebanyak 1.187 .670 orang, kemudian pada 2013 turun menjadi sebanyak 1.114.269 orang, dan pada 2014 turun lagi menjadi sebanyak 1.026.328 orang. Berdasarkan survai di lapangan, dari jumlah wisatawan yang tersebut di atas, sekitar $80 \%$ diantaranya didominasi wisatawan yang berkunjung ke tempat obyek wisata budaya, yakni Masjid Menara Kudus, dan Makam Sunan Muria. Sisanya yang 20\%, berkunjung ke obyek wisata alam, yakni Air Terjun Montel, Rejenu (air tiga rasa), Rahtawu, Situs Patiayam, dan tempat wisata buatan, Taman Krida Wisata, di Komplek GOR Wergu Wetan, dan Taman Ria Anak-Anak di Colo, Kecamatan 
Dawe. Mengenai keberadaan obyek wisata Colo, keunggulannya sebagai wisata religi sudah terbukti mampu menyumbangkan Pendapatan Asli Daerah (PAD) terbesar di sektor pariwisata. Pada 2014 lalu, obyek wisata Colo, menyumbangkan PAD sebesar Rp 351.824.000, dari total PAD sebesar Rp 1,1 miliar [3].

Dengan masalah yang dialami, untuk meningkatkan sektor wisatawan di kota Kudus maka kami melakukan penelitian di bidang kuliner. Dengan mengangkat tema kuliner ini diharapkan dapat membantu meningkatkan wisatawan di Kota Kudus. Untuk itu kami melakukan penelitian dalam memberikan kemudahan akses kuliner kota Kudus. Hasil dari penelitian ini adalah sebuah aplikasi pencarian wisata kuliner yang ada di kota Kudus berbasis android.

\section{Kajian Pustaka}

Secara geografis, letak Kabupaten Kudus cukup strategis, karena berada di jalur perlintasan ekonomi antarprovinsi sehingga menjadikan Kota Kudus sebagai sentra perdagangan nasional yang memiliki mobilitas tinggi. Kudus sebagai salah satu kawasan perdagangan di Pulau Jawa juga berpotensi menjadi pusat perdagangan (Trade Centre) berskala Internasional. Keunggulan Kabupaten Kudus sebagai salah satu kabupaten yang proinvestasi di Jawa Tengah juga dibuktikan dengan ditetapkannya Kabupaten Kudus sebagai Kabupaten/Kota Proinvestasi peringkat IV dari 32 Kabupaten/Kota se-Jawa Tengah.

Padahal, dari sisi luas wilayahnya Kabupaten Kudus dianggap paling kecil di Jawa Tengah dengan luas wilayah hanya 42.516 hektare. Jumlah penduduk kabupaten ini, berdasarkan hasil sensus penduduk 2012 sebanyak 791.891 orang terdiri atas 391.722 laki-laki dan 400.169 perempuan. Seks ratio Kabupaten Kudus adalah sebesar 97,89 yang artinya jumlah penduduk laki-laki lebih sedikit dibandingkan dengan jumlah penduduk perempuan. Wilayah Kabupaten Kudus berbatasan dengan Kabupaten Jepara dan Pati di sebelah utara, Kabupaten Pati di sebelah timur, Kabupaten Grobogan di sebelah selatan, dan Kabupaten Demak di sebelah barat.

Kudus merupakan daerah industri dan perdagangan yang mampu menyerap banyak tenaga kerja dan memberikan kontribusi besar terhadap PDRB. Tingkat kesejahteraan warga yang semakin meningkat, juga ikut menggerakkan sektor usaha kuliner yang mulai menjamur di setiap sudut Kota Kudus.

Makanan khas Kota Kudus yang cukup dikenal di Tanah Air, meliputi garang asem, soto Kudus, satai kerbau, dan jenang.
Beberapa tahun terakhir, warung makan yang menyajikan garang asem tidak terbatas di lokasi tertentu, karena saat ini sudah menjamur di sejumlah warung makan juga menyediakan garang asem. Hal ini, secara tidak langsung menunjukkan tingkat kesejahteraan warganya juga mengalami perbaikan, karena konsumen penikmat makanan khas tersebut juga banyak.

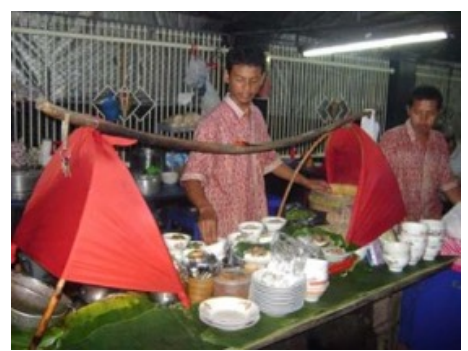

Gambar 1 Salah satu wisata kuliner di kota Kudus

Pengertian Android adalah sebuah sistem operasi mobile yang open-source dan dikembangkan oleh Google. OS Android digunakan untuk komputer tablet dan smartphone. Namun berdasarkan dari arti kata dan wujudnya, Android merupakan sebuah robot pintar yang dibuat menyerupai manusia. Pengguna android di Indonesia menurut Lembaga riset Sharing Vision belum lama ini mempublikasikan hasil penelitiannya terhadap pengguna Android di Indonesia sepanjang 2013. Pada 2013 sistem operasi Android menguasai sekitar 60\% smartphone beredar di Indonesia. Pertumbuhan pengguna android mencapai lebih dari 1,5 juta per hari di global. Diungkapkannya, aplikasi yang paling sering digunakan pengguna Android di Indonesia adalah Whatsapp (80\%) dan mayoritas $(97 \%)$ responden mengakui bahwa mereka bergabung dengan grup [4].

\subsection{Penelitian Terkait}

Peneitian terkait dengan tema ini salah satunya adalah aplikasi mobile berbasis android. Penelitian ini memiliki tujuan yang ingin dicapai yaitu merancang suatu aplikasi mobile berbasis Android yang mampu memberikan informasi kepada para wisatawan tentang lokasi objek wisata yang terdapat di wilayah Kota dan Kabupaten Tegal. Hasil yang diharapkan dengan adanya aplikasi ini yaitu dapat membantu, mempermudah, dan mempercepat wisatawan dalam mencari dan memperoleh informasi tentang lokasi objek wisata yang terdapat di Kota dan Kabupaten Tegal [5].

Penelitian kedua tentang pengembangan aplikasi pencarian lokasi objek wisata terdekat di kabupaten garut berbasis android adalah aplikasi dari sistem 
terkomputerisasi dalam bidang teknologi informasi. Metodologi yang di pakai dalam perancangan ini adalah dengan Object Oriented Desain (OOD) dari Unified Approach (UA) Ali Bahrami (1999). Adapun tahapan perancangan yang digunakan yaitu berdasarkan tahapan Object Oriented Desain (OOD) dari Unified Approach (UA) Ali Bahrami (1999). Perancangan sistem masa depan merupakan tahapan setelah melakukan proses analisis. Dalam perancangan terdapat beberapa tahapan yang dilakukan yaitu perancangan kelas, metode, atribut, dan asosiasi, menyaring UML Class Diagram, perancangan layer akses dan layer antarmuka, dan terakhir yaitu proses pengujian. Ali Bahrami (1999). Dari hasil penelitian tugas akhir ini dapat ditarik kesimpulan bahwa adanya Aplikasi Pencarian Lokasi Objek Wisata Terdekat di Kabupaten Garut Berbasis Android ini memudahkan pengguna dalam memperoleh informasi mengenai lokasi wisata disertai dengan fasilitas-fasilitas yang berada di sekitar objek wisata yang dituju secara lengkap dan detail [6].

\section{Hasil Percobaan}

\subsection{Perancangan}

Perancangan pada aplikasi wisata kuliner kota Kudus menggunakan pemodelan use case. Pada Gambar 4 terdapat 1 aktor yang bernama user dan use case di dalamnya. User dapat mengakses 6 use case secara langsung tanpa ada syarat yang lain. Pada use case Home, user dapat melihat halaman utama dari aplikasi wisata kuliner. Untuk melihat detail makanan, lihat gambar, detail news, user harus mengakses terlebih dahulu jenis makanan/ galer/ wikulku news. Namun pada social media, user dapat memilih salah satu isi di dalamnya, seperti facebook, linkedid, twitter ataupun instagram.

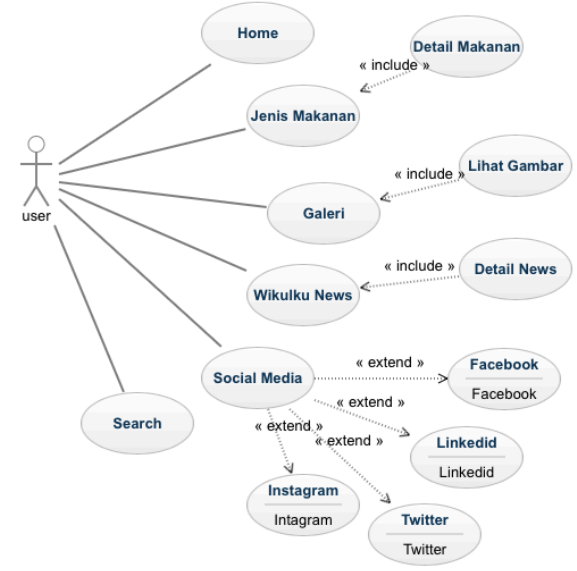

Gambar 2 Use case aplikasi wisata kuliner kota Kudus
Pada perancangan Gambar 3 menjelaskan aktor admin yaitu orang yang berhak melakukan update isi dari aplikasi wisata kuliner ini. Pada use case ini aktor admin dapat melakukan aktifitas jika melakukan login terlebih dahulu. Setelah login admin dapat melakukan tambah artikel, setting tema, tambah gambar, lihat statistik dan logout.

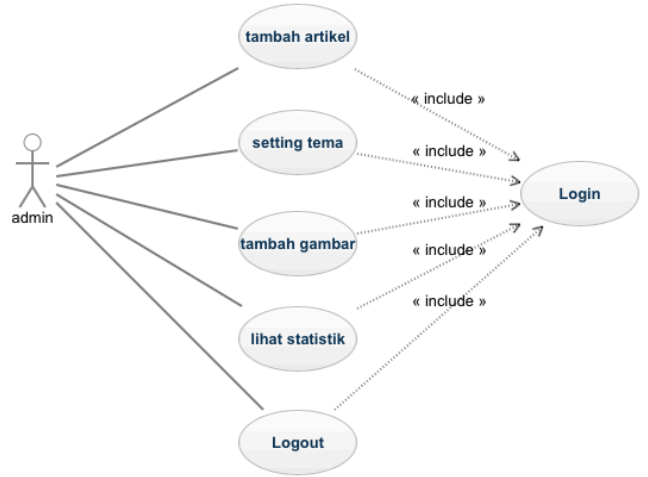

Gambar 3 Use case admin

\subsection{Hasil Penelitian}

Hasil dari penelitian yang berjudul Aplikasi Wisata Kuliner Kota Kudus Berbasis Android menghasilkan sebuah aplikasi android. Di mana aplikasi android tersebut dapat diunduh pada sebuah media uploader. Aplikasi ini di beri nama WiKUlKu yang berarti Wisata Kuliner Kudus.

Langkah awal yang dilakukan adalah melakukan instalasi file apk wikulku terlebih dahulu. Pada gambar 4 merupakan tampilan icon dari aplikasi wikulku. Data makanan khas didapatkan dari survei langsung serta dari website kabupaten Kudus. Proses memasukkan data dilakukan oleh tim peneliti dalam beberapa hari.

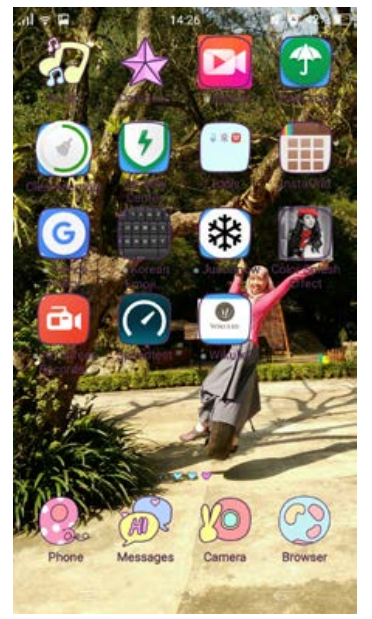

Gambar 4 Aplikasi Wikulku di HP dengan platform android 
Setelah file apk sudah didapat, langkah selanjutnya ada melakukan instalasi seperti pada Gambar 5.

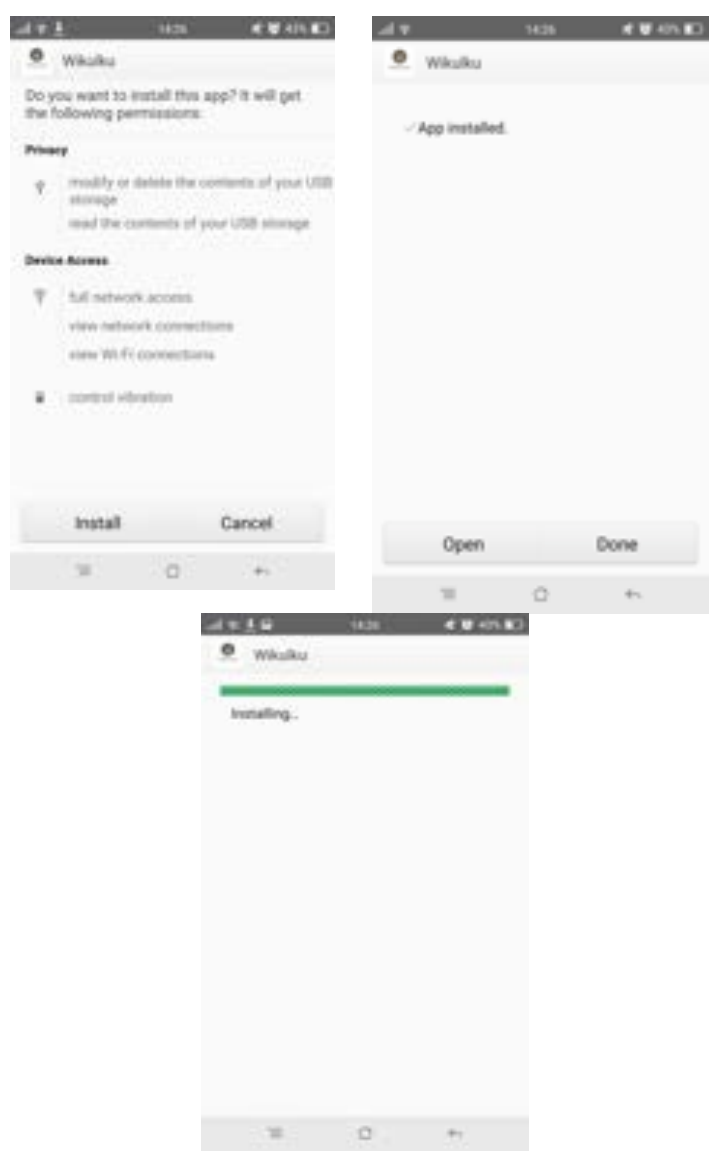

Gambar 5 Proses instalasi wikulku

Aplikasi wikulku dapat digunakan sebagai mana aplikasi pada android umumnya. Pada aplikasi wikulku ini, kita dapat mencari info tentang masakan daerah/khas kota Kudus. Pada Gambar 6 merupakan tampilan awal dari aplikasi Wikulku yang berisi logo dari Wikulku.

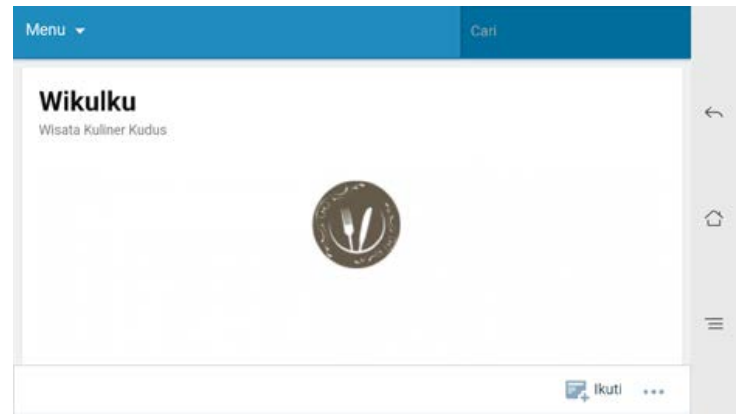

Gambar 6 Halaman utama dari Wikulku
Pada menu berisi tentang media sosial wikulku, yang terdiri dari facebook, linkedln, twitter dan instagram. Menu tersebut dapat dilihat pada Gambar 7.

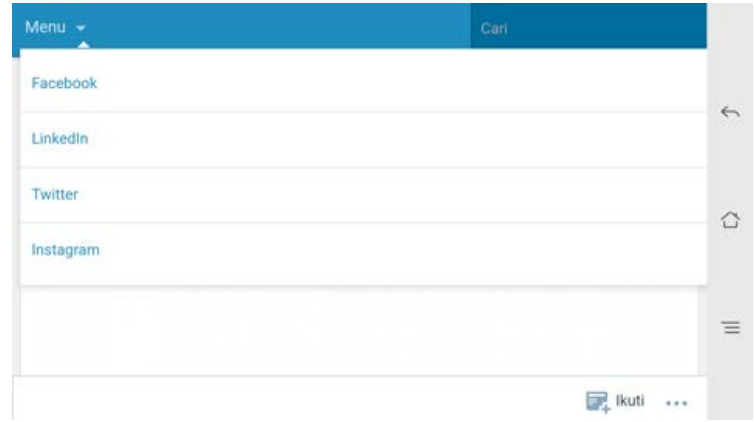

Gambar 7 Media Sosial dari Wikulku

Pada Gambar 8 merupakan salah satu makanan khas Kudus yang dapat di lihat pada aplikasi wisata kuliner khas Kudus.

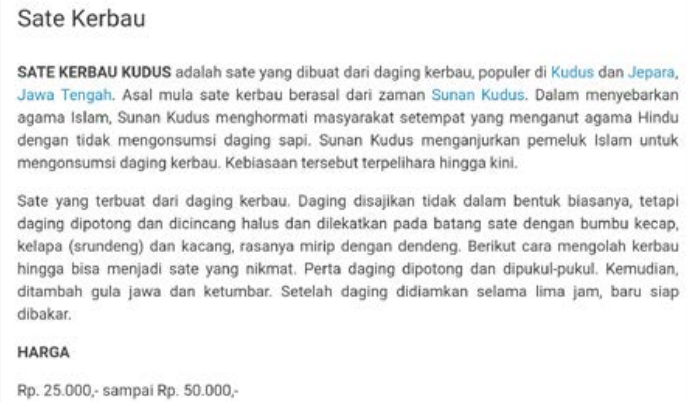

Sate yang terbuat dari daging kerbau. Daging disajkan tidak dalam bentuk biasanya, tetapi daging dipotong dan dicincang halus dan dilekatkan pada batang sate dengan bumbu kecap. kelapa (srundeng) dan kacang, rasanya mirip dengan dendeng. Berikut cara mengolah kerbau hingga bisa menjadi sate yang nikmat. Perta daging dipotong dan dipukul-pukul. Kemudian, ditambah gula jawa dan ketumbar. Setelah daging didiamkan selama lima jam, baru siap dibakar.

HARGA

Rp. 25.000, sampai Rp. 50.000.

Gambar 8 Halaman makanan khas Kudus

Galeri pada aplikasi wikulku dapat dilihat seperti pada Gambar 9. Pada galeri ini dapat disetting jumlah gambar yang akan dimunculkan.

\section{WIKULKU}

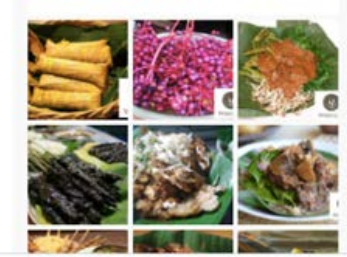


Pada gambar 10 dapat dilihat detail dari makanan khas Kudus. Pada halaman ini berisi gambar, keterangan dari makanan khas Kudus, info kisaran harga dan peta dari salah satu penjual makanan khas Kudus ini.

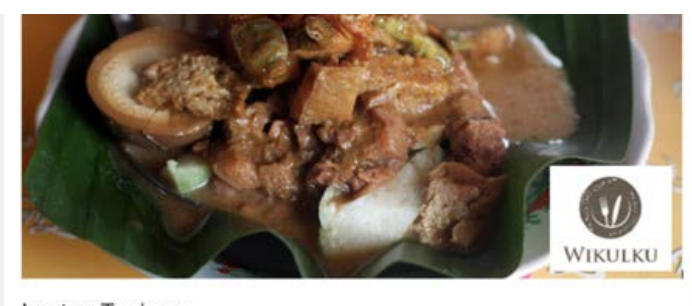

Lentog Tanjung

LENTOG artinya Lontong. Dahulu, penjualnya berasal dari Desa Tanjungkarang (Tanjung). Maka dinamai Lentog Tanjung. Namun kini telah menyebar ke seluruh pelosok kota Kudus. Yang unik ari lentog adalah ukuran lontongnya yang sebesar betis orang dewase. Biasanya lentog tanjung

Gambar 10 Detail dari makanan khas Kudus

Aplikasi wikulku juga dilengkapi dengan link untuk menampilkan maps dari salah satu penjual dari makanan khas Kudus. Di sini menggunakan fasilitas google maps. Di mana pada google maps selain menampikan peta dari tempat yang dituju juga dapat membantu kita untuk menuju tempat tersebut. Dengan fasilitas direction, kita ditunjukkan arah dari tempat kita berada menuju tempat yang dituju seperti yang ditunjukkan pada Gambar 11 . Pada Gambar 12 merupakan konfirmasi jika kita akan keluar pada aplikasi wikulku ini.

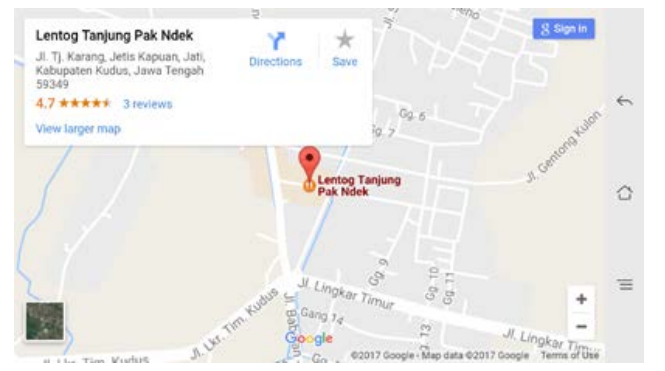

Gambar 11 Maps/peta dari salah satu penjual makanan khas Kudus

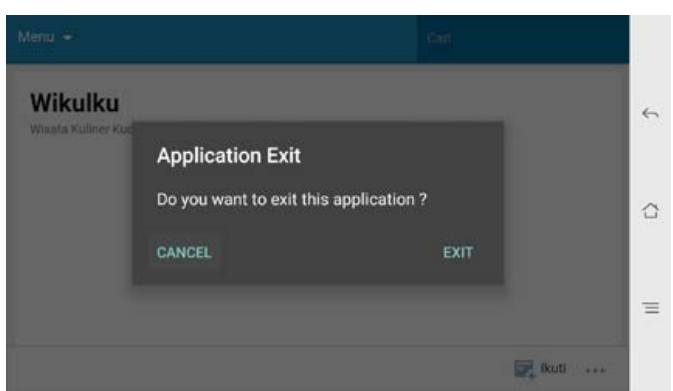

Gambar 12 Konfirmasi keluar dari aplikasi

\subsection{Pengujian}

Pengujian yang dilakukan dengan tujuan untuk mengetahui sejauh mana kualitas aplikasi, apakah sudah memenuhi harapan atau belum. Untuk itu dalam pengujian betha dilakukan penelitian terhadap responden atau pengguna aplikasi dengan melakukan pengumpulan data menggunakan kuesioner atau angket. Metode yang digunakan adalah dalam penelitian ini adalah metode kuantitatif.

Sebelum melakukan pengujian aplikasi dibagikan ke media uploader, seperti google drive dan 4shared. Hal ini dilakukan untuk sharing melalui media maya. Pada Gambar 13 dan 14 merupakan penyebaran melalui website uploader 4shared.com. Link yang dapat diakses oleh masyarakat untuk mendapatkan aplikasi wikulku adalah: https://tinyurl.com/wikulku

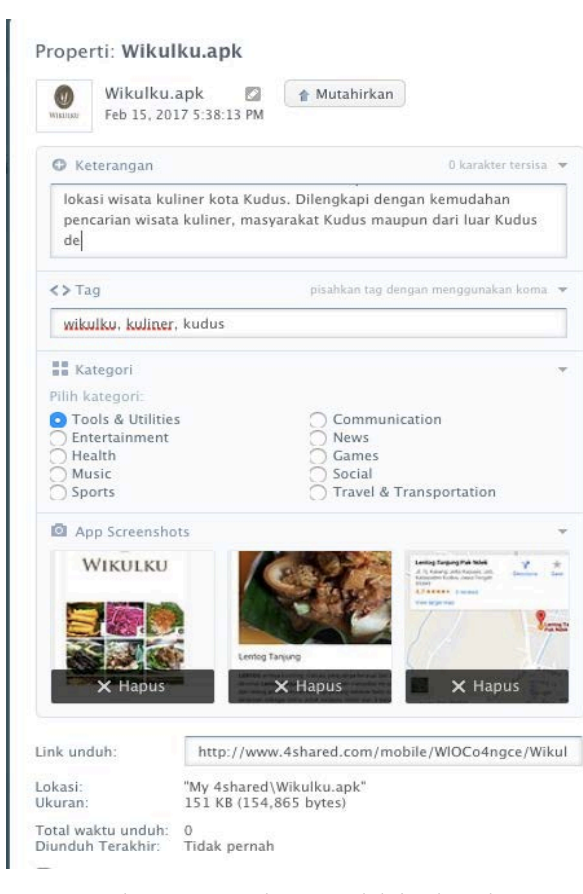

Gambar 13 Penyebaran melalui 4shared.com

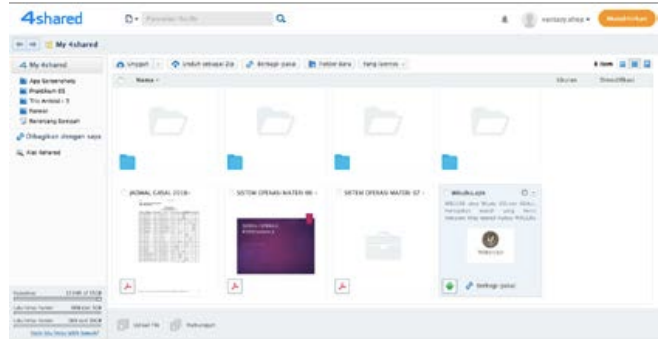

Gambar 14 Halaman 4shared.com 
Pada Gambar 15 merupakan salah satu penyebaran aplikasi wikulku dengan media google drive. Dengan di upload pada google drive, masyarakat dapat mencoba aplikasi pada link sebagai berikut.

https://tinyurl.com/wikulku-drive

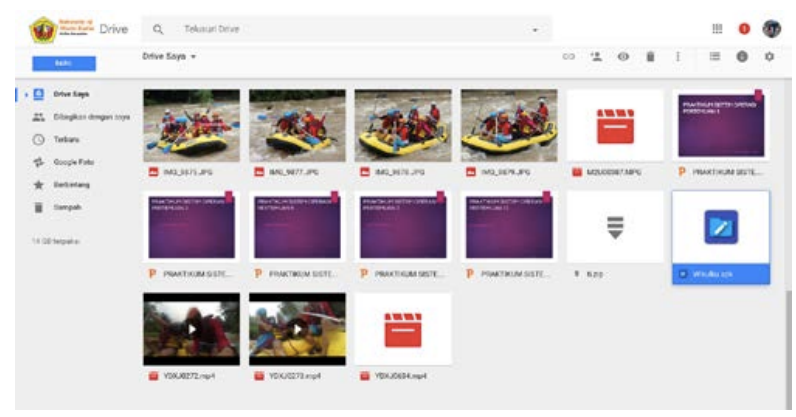

Gambar 15 Penyebaran melalui google drive

Pengujian dilakukan dengan melihat statistik dari aplikasi, diantaranya rating per hari, posting makanan yang paling populer, jumlah liker. Pada gambar 16 merupakan ringkasan per hari. Data yang diambil adalah tanggal 15 Februari 2017. Pada Gambar 17 merupakan statistik posting makanan khas Kudus yang paling populer diakses. Sedangkan pada gambar 18 adalah URL yang mengakses aplikasi wikulku.

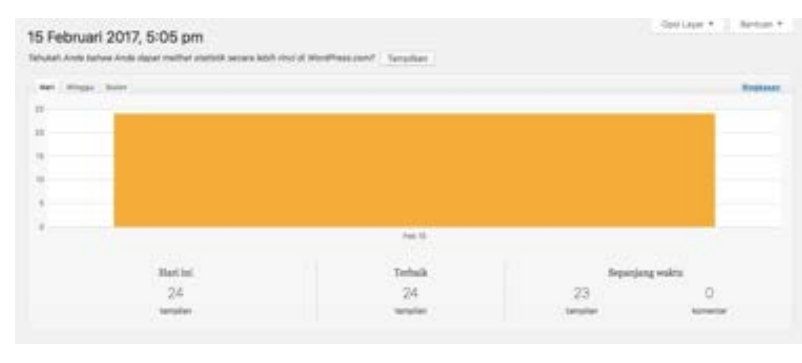

Gambar 16 Jumlah ringkasan aplikasi per hari

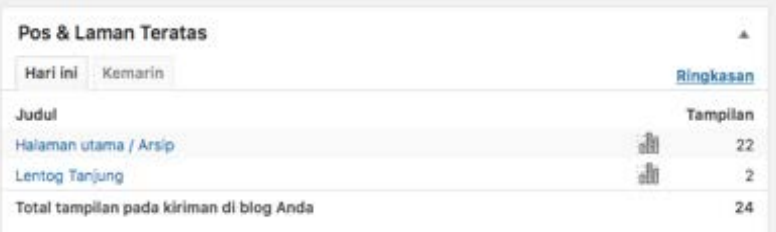

Gambar 17 Posting teratas pada wikulku

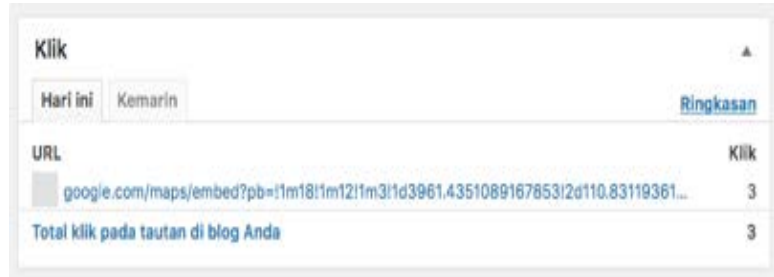

Gambar 18 Link yang mengakses wikulku melalui web

\section{Kesimpulan}

\subsection{Kesimpulan}

Dari pembahasan penelitian yang telah diuraikan, maka peneliti dapat menarik beberapa kesimpulan, antara lain:

1. Aplikasi wisata kuliner Kudus dapat digunakan menggunakan smartphone yang berbasis android dan juga dapat diakses melalui website https://wikulku.wordpress.com

2. Aplikasi ini dilengkapi dengan fasilitas yang diberikan oleh google map, yang dapat digunakan untuk mencari letak dari salah satu penjual makanan khas Kudus.

3. Dari statistik website, per hari dilihat kurang lebih 25 viewer.

\subsection{Saran}

Demi meningkatkan penelitian ini, peneliti menerima beberapa saran untuk peneliti berikutnya dalam mengembangkan aplikasi ini, diantaranya:

1. Aplikasi wisata kuliner Kudus berbasis android belum dapat diupdate secara otomatis, harus menambahkan melalui website terlebih dahulu.

2. Aplikasi wisata kuliner ini belum tersedia pada google playstore.

\section{REFERENSI}

[1] Nahkodaku, "nahkodaku.com," Nahkodaku, 1 Januari 2015. [Online]. Available: http://www.nakhodaku.com/2015/10/cerita-sejarah-dan-asalusul-kota-kudus.html. [Accessed 14 Oktober 2016].

[2]. R. Atmasari, "pojoksatu.id," 1 Juli 2016. [Online]. Available: http://pojoksatu.id/life-style/2016/07/01/10kuliner-kudus-ini-dijamin-pecah-dimulut/. [Accessed 14 Oktober 2016].

[3] E. Santoso, "isknews.com," 29 Juli 2015. [Online]. Available: $\mathrm{http} / /$ isknews.com/grafik-angka-kunjungan-wisata-di-kudusalami-penurunan/. [Accessed 14 Oktober 2016].

[4]. T. Listyorini, 2014, "3d-Catalog Mountain View Resident Berbasis Augmented Reality," in SAINTIKS, Bandung. 
[5]. B. N. S. M. Akhmad Agus Wijayanto, 2013, "APLIKASI MOBILE LOKASI OBJEK WISATA KOTA DAN KABUPATEN TEGAL BERBASIS ANDROID," UDINUS, Semarang.

[6]. S. Rizal, 2013, "Pengembangan Aplikasi Pencarian Objek Wisata di Kabupaten Garut Berbasis Android," Jurnal Algoritma, vol. 10, no. 1, pp. 1-14.

Tri Listyorini, memperoleh gelar S.Kom dan M.Kom dari Universitas Dian Nuswantoro Semarang tahun 2007 dan 2010. Saat ini sebagai Staf Pengajar program studi Teknik Informatika Universitas Muria Kudus.

Rizkysari Meimaharani, memperoleh gelar S.Kom dan M.Kom dari Universitas Dian Nuswantoro Semarang tahun 2007 dan 2010. Saat ini sebagai Staf Pengajar program studi Teknik Informatika Universitas Muria Kudus. 